\title{
Host-plant flowering status and the concentration of sugar in phloem sap: Effects on an ant-treehopper interaction
}

\author{
Tiago B. QUENTAL*, José R. TRIGO and Paulo S. OLIVEIRA** \\ Departamento de Zoologia, C.P. 6109, Universidade Estadual de Campinas, 13083-970 Campinas SP, Brasil
}

\begin{abstract}
Keywords. Ant-treehopper association, honeydew, host-plant mediation, host-plant quality, Membracidae, mutualism, phloem sugar, tritrophic interaction, cerrado savanna
\end{abstract}

\begin{abstract}
Host-plant mediation in ant-hemipteran mutualisms requires three conditions. First, hemipteran attractiveness to ants should vary with plant quality. Second, ants should preferentially tend those Hemiptera that produce the most nutritious attractant. Third, increased ant attendance based on a richer food reward should have a significant effect on some measure of hemipteran fitness. A field experiment is used to test these conditions. This is the first study to simultaneously test these three conditions, and the first to test the effect of plant flowering status on the ant-derived benefits for a honeydew-producing hemipteran. It is hypothesized that membracids (Guayaquila xiphias) feeding on plants (Didymopanax vinosum) with flowers ingest phloem sap of higher quality (higher sugar concentration), produce a higher-quality honeydew and, as a result, are attended by more ants and are better protected compared to those on plants without flowers. Total nitrogen content of the phloem sap of plants with or without flowers did not differ significantly, whereas the sugar concentration was higher in the sap of plants with flowers. Honeydew sugar concentration, honeydew production, and ant tending levels did not vary significantly with flowering status. Membracid survival increased, and natural enemy abundance decreased when ants were present. Plant flowering status did not affect the ant-derived protection afforded to treehoppers, but plants with flowers accumulated more natural enemies through time than plants without flowers. The results suggest that a trade-off between feeding on a higher-quality food and running increased risk of predation on flowering plants could underlie this ant-hemipteran interaction. Based on the parameters measured in this study it is concluded that host-plant mediation does not occur in the ant-Guayaquila system. The results suggest, however, that the way in which the host-plant could affect ant-Guayaquila interactions is complex and likely to involve other species.
\end{abstract}

\section{INTRODUCTION}

Although traditionally viewed as a static interaction, ant-plant and ant-herbivore mutualisms have more recently been investigated within a cost/benefit framework (e.g., Pierce et al., 1987; Stadler \& Dixon, 1998; Bronstein \& Barbosa, 2002). Studies on several systems, including ant-hemipteran interactions, have shown that the outcome of an association is contingent upon biotic and abiotic factors that change the costs and benefits for each species involved in the interaction (Bronstein \& Barbosa, 2002; Oliveira \& Freitas, 2004, and references therein). Manipulative studies have revealed that the outcome of ant-hemipteran interactions can depend on factors such as hemipteran age, identity and/or density of the species involved, as well as type and abundance of natural enemies (Cushman \& Whitham, 1989; Cushman \& Addicott, 1989, 1991; Del-Claro \& Oliveira, 2000).

The honeydew produced by phloem-feeding Hemiptera is rich in sugars (Auclair, 1963; Völkl et al., 1999) and for many ant species these secretions represent an important food resource (Rico-Gray, 1993; Davidson et al., 2003). Tending ants harvest the honeydew produced by Hemiptera, and in turn provide a wide range of benefits, including protection from predators and parasitoids (Way, 1963; Bristow, 1984; Cushman \& Whitham, 1989; DelClaro \& Oliveira, 2000) and increased fecundity
(McEvoy, 1979). Occasionally, ant-tended Hemiptera may also benefit from increased feeding rates, reduced fungal infections and ant-constructed protective shelters (Buckley, 1987; Queiroz \& Oliveira, 2001; Oliveira et al., 2002).

Plant characteristics such as the chemical composition of phloem sap can directly affect the survival and reproduction of insect herbivores such as phloem-feeding Hemiptera (Auclair, 1963; Mattson, 1980). Indeed, variation in host-plants (within an individual plant, within a species, or among species) influences the amount of honeydew produced as well as the nature and concentration of the chemical compounds it contains (Auclair, 1963; Dixon, 1985, Hendrix et al., 1992; Fischer \& Shingleton, 2001). Since the secretions produced by ant-tended herbivores are derived in part from their host-plants, variation in the quality of phloem sap is thought to indirectly affect the ability of herbivores to attract ants (Strong et al., 1984; Pierce, 1985). If host-plant quality mediates the outcome of a mutualism between ants and herbivores, a characteristic tritrophic relationship (Price et al., 1980), then three conditions must be met to account for this mediation (see Cushman, 1991). First, the attractiveness of herbivores to ants (due to the chemical composition and/or quantity of the ant attractant produced by the herbivores) should vary with host-plant quality. Second, ants

\footnotetext{
* Current address: Department of Organismic and Evolutionary Biology, Harvard University, 02138 Cambridge MA, USA .

** Corresponding author; e-mail: pso@unicamp.br
} 
should preferentially tend those herbivores that produce the most nutritious attractant. Third, the increased number and/or attentiveness of ants should significantly affect herbivore fitness.

In the field study reported here, the three conditions were tested simultaneously by considering the presence or absence of flowers on a particular species of host-plant as a possible mediating factor of an ant-Hemiptera mutualism. Although host-plant flowering phenology is known to determine the feeding location of membracids (Wood, 1980; Price \& Carr, 2000) the degree to which plant flowering status can affect ant-membracid interactions has never been addressed experimentally. This study is centred on the interaction between tending ants and the honeydew-producing treehopper Guayaquila xiphias (Fabricius, 1803) (Hemiptera: Membracidae) on the plant, Didymopanax vinosum March. (Araliaceae). In general, at the onset of reproduction, plants increase the allocation of resources to reproductive stems, resulting in an increase in the quality of the phloem sap in flowering/fruiting plants (White, 1984; Salisbury \& Ross, 1992). Because membracids feed on phloem sap, their choice of flowering versus non-flowering host-plants could affect the benefits they are afforded by honeydew-gathering ants. Specifically, this study tested the hypothesis that membracids on flowering plants consume a higher quality food, which results in a higher quality honeydew for ants, increased ant attendance and better protection compared to membracids on non-flowering plants. The quality of phloem sap (i.e., nutritional value) is expressed in terms of soluble sugar and total nitrogen. Because nitrogen concentration did not vary with plant flowering status (see below) and sugar content is regarded as an important factor in ant-hemipteran interactions, honeydew quality is evaluated in this study in terms of sugar concentration (see Kiss, 1981; Völkl et al., 1999; Woodring et al., 2004). The field experiment was designed to address the following questions: (1) Does the quality of phloem sap (sugar concentration) vary between plants with and without flowers? (2) Does the presence of flowers (and thus membracid feeding location) affect (a) honeydew quality and/or quantity; (b) membracid attractiveness to ants; (c) protection to membracids by ants; (d) the abundance of the natural enemies of the membracid on the host-plants?

\section{The study system}

The ant-Guayaquila xiphias system is present all yearround in the Brazilian cerrado (sub-tropical savanna) and involves a diverse assemblage of honeydew-gathering ants that forage on the membracid's host plant, Didymopanax vinosum (Del-Claro \& Oliveira, 1999). Guayaquila membracids usually feed near the apical meristem of the principal stem of non-reproductive plants, but if the plant is flowering they feed on stem of the main inflorescence (Fig. 1). The single flower stem bears 1 to 3 inflorescences (for further details on the biology of the membracid and host plant see Del-Claro \& Oliveira, 1999). Three main types of natural enemies attack Guayaquila membracids on plants: salticid spiders (15 species may prey on nymphs and adults), predatory larvae of the syrphid Ocyptamus arx (Fluck, 1936) (suck out the body contents of nymphs and adults) and myrmarid parasitoid Gonatocerus (attacks egg masses) (Del-Claro \& Oliveira, 2000). Tending ants effectively defend the membracids against all three types of natural enemies, and membracid fecundity is also increased because females transfer brood care to ants and produce an extra clutch (Del-Claro \& Oliveira, 2000). If not tended by ants, the treehoppers eject the accumulated honeydew beneath the host-plant and attract ground-dwelling ants that climb onto the plant and begin tending activities (Del-Claro \& Oliveira, 1996). The host-plant does not have any means of attracting ants, such as extrafloral nectaries, and the spatial distribution and patrolling activity of ants on the foliage is determined by the location of membracid aggregations, although occasional scout ants are seen on shrubs free of treehoppers (Del-Claro \& Oliveira, 2000). The importance of Guayaquila honeydew for cerrado ants is such that even in the presence of an alternate sugar source tending levels remain unchanged (Del-Claro \& Oliveira, 1993). Moreover, some species of ants may tend the treehoppers all day and build satellite nests to house them (Oliveira et al., 2002).

\section{METHODS}

Fieldwork was carried out in the cerrado reserve of the Estação Experimental de Mogi-Guaçu, São Paulo State in southeastern Brazil $\left(22^{\circ} 18^{\prime} \mathrm{S}, 47^{\circ} 10^{\prime} \mathrm{W}\right)$. The vegetation consists of a dense scrub of shrubs and trees, which is the cerrado sensu stricto (Oliveira-Filho \& Ratter, 2002). Observations and experiments were performed in the flowering season, over a period of 16 consecutive days in February and March 2001, between 0800 and $1600 \mathrm{~h}$. However, due to the daily turnover in the species of ants tending the treehoppers, observations were also made at night to determine the species of nocturnal ant attendants on the experimental plants (see below).

A total of $56 \mathrm{D}$. vinosum plants (1-2 $\mathrm{m}$ tall) were individually tagged and randomly assigned as control (ants present) or experimental (ants excluded) plants. At the start of the experiment all tagged plants already hosted one aggregation of honeydew-producing Guayaquila (no membracid was placed on, or removed from plants), and were naturally free of myrmecophilous lycaenid larvae or other ant attractants (Oliveira \& Del-Claro, 2005). Ants were excluded from experimental plants by a sticky barrier of tanglefoot (Tanglefoot ${ }^{\circledR}$ Co., Grand Rapids, MI, U.S.A.) at the base of each plant. Bridges of vegetation between plants, which might have enabled ants to access the experimental plants, were regularly pruned. Two kinds of plants were used: plants with inflorescences (hereafter with flowers) and plants without inflorescences (hereafter without flowers). This resulted in four treatments (Table 1): plants (i) with flowers and ants $(n=14)$, (ii) with flowers and without ants $(n=13)$, (iii) without flowers but with ants $(n=15)$ and (iv) without both flowers and ants $(n=14)$. All plants used in the experiment were growing along the same trail in the cerrado area. We recorded (1) the number of treehoppers, (2) their natural enemies (spiders, syrphid fly larvae and parasitic wasps), and (3) the number of tending ants on the 1st, 9th, and 16th day of the experiment (treehopper densities on "Day 1" did not differ among treatments; see below). Tending ants were counted at 0900 and $1500 \mathrm{~h}$, and at 2100 and $0300 \mathrm{~h}$. Due to the low numbers, the data for the three types of natural enemies were pooled 


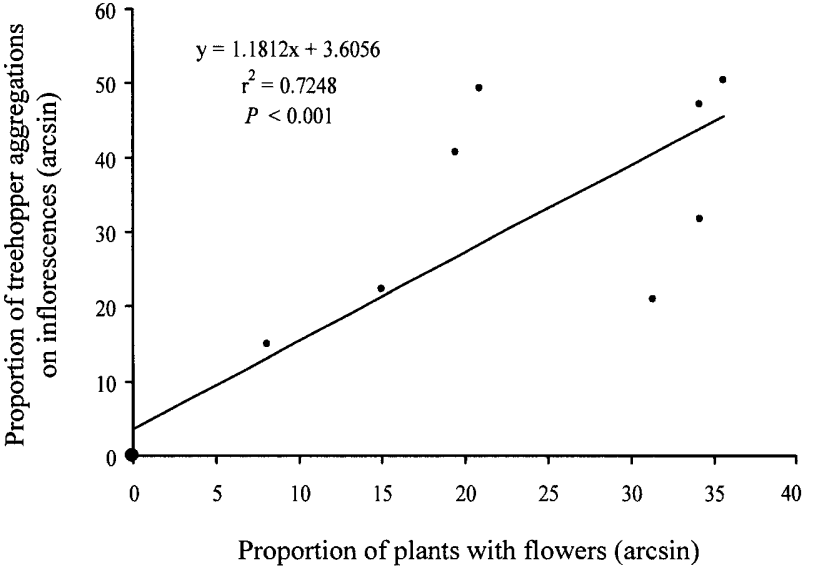

Fig. 1. Relationship between the feeding site of Guavaquila xiphias treehoppers and the flowering phenology of Didymopanax vinosum shrubs in the cerrado savanna over a period of 12 months. Feeding sites were categorized as inflorescence, and stem or apical meristem. Sixty plants were monitored monthly for a year (based on data from Del-Claro \& Oliveira, 1999).

(for a separate treatment of each natural enemy, see previous paper on this system by Del-Claro \& Oliveira, 2000). Since newly-eclosed adult treehoppers begin to disperse from natal aggregations ca. 20 days after hatching from eggs, the 16-day duration of the ant-exclusion experiment was a priori considered adequate for evaluating the effects ant-tending on Guayaquila (cf., Del-Claro \& Oliveira, 2000). Flowering in D. vinosum occurs from February to September and peaks from March to June. The flowers on a single plant last ca. 40 to 90 days. Because treehoppers aggregate near inflorescences during the flowering season (Fig. 1), it was not possible to compare antmembracid interactions adjacent to flowers and away from flowers on the same plant.
Three repeated-measures anovas were performed: (i) to compare ant-tending levels over time of treehopper aggregations infesting either flowering or non-flowering plants, (ii) to investigate whether plant flowering status and ant treatment affect the abundance of $G$. xiphias, and (iii) to investigate whether plant flowering status and ant treatment affect the abundance of natural enemies. The data were square-root transformed to meet assumptions of normality and homoscedasticity (Zar, 1999), but untransformed data are presented in the figures to facilitate viewing and interpretation.

Chemical analyses of the phloem sap of $D$. vinosum were performed on material collected from an additional 14 plants without flowers and 12 with flowers (the plants in these two groups were the same height; $t_{24}=0.413, P=0.68$ ). Plants used in the phloem sap analyses were not infested with treehoppers. Phloem sap was collected by cutting the principal stem of the tagged plants and placing the cut end in a tube with a solution of $20 \mathrm{mM}$ EDTA (after King \& Zeevaart, 1974). These stems were oven dried and weighed. Soluble sugar and total nitrogen content of the phloem sap in each sample were calculated and normalised for the dry weight of the respective stems. Stems of the plants of the two groups were the same weight $\left(t_{24}=-0.520, P=\right.$ 0.61 ). Soluble sugar concentration was determined by the anthrone method, following Kearns \& Inouye (1993). Total nitrogen content was determined by the Kjeldahl method (Vogel, 1989). Data were square-root transformed to normalise treatment variances prior to statistical analyses. Results were compared using $t$-tests.

Honeydew production by the treehoppers was estimated for aggregations (13 to 201 individuals) infesting similar-sized $D$. vinosum plants with $(n=7)$, and without flowers $(n=8)$. The size of treehopper aggregations did not differ between the two groups of plants $\left(t_{13}=0.300, P=0.769\right)$. Only aggregations on plants from which ants were artificially excluded were used. Because little variation was detected in the size of the honeydew droplets $(\approx 0.7 \mathrm{~mm}$ diameter) produced by the membracids (cf., Del-Claro \& Oliveira, 1993) honeydew production is expressed

TABLE 1. Initial treehopper densities in the four treatments (mean $\pm \mathrm{SE}$ ), and composition of ant assemblages tending treehopper aggregations on plants with or without flowers recorded both by day and night. Data on aggregation size are from "Day 1" of the field experiment.

\begin{tabular}{lcc}
\hline Treatments & Initial aggregation size & No. of aggregations \\
\hline Plants with flowers/with ants & $20.64 \pm 5.20$ & 14 \\
Plants with flowers/without ants & $21.46 \pm 11.52$ & 13 \\
Plants without flowers/with ants & $18.13 \pm 6.16$ & 15 \\
Plants without flowers/without ants & $26.43 \pm 10.83$ & 14 \\
\hline
\end{tabular}

\begin{tabular}{lcc}
\hline Ant species active by day & Ant species active at night & 5 \\
\hline Plants with flowers & & 5 \\
Camponotus crassus & Camponotus renggeri & 1 \\
Camponotus aff. blandus & Camponotus abdominalis & 6 \\
Camponotus aff. blandus & Camponotus renggeri & 2 \\
Camponotus rufipes & Camponotus rufipes & 14 \\
Total no. of aggregations & & 7 \\
Plants without flowers & Camponotus renggeri & 1 \\
Camponotus crassus & Camponotus abdominalis & 3 \\
Camponotus aff. blandus & Camponotus renggeri & 3 \\
Camponotus aff. blandus & Camponotus rufipes & 1 \\
Camponotus rufipes & Camponotus renggeri & 15 \\
Camponotus renggeri & & \\
Total no. of aggregations & & \\
\hline
\end{tabular}


TABLE 2. Repeated-measures ANOVA performed on (a) the number of ants per treehopper and (b) the absolute number of ants per aggregation through time, on plants with $(n=14)$ or without flowers $(n=15)$. Calculations performed on square-root transformed data collected on the 1st, 9th, and 16th day of the field experiment. See also Fig. 2.

\begin{tabular}{lcccccc}
\hline \multicolumn{1}{c}{ (a) Ants per treehopper } & df & Mean of square & df error & Mean of square error & $F$ & $P$ \\
Host-plant flowering & & & & & & \\
Time (day of experiment) & 1 & 0.04 & 26 & 0.45 & 0.073 & 0.780 \\
Host-plant flowering $\times$ time & 2 & 0.20 & 52 & 0.17 & 1.411 & 0.298 \\
$\quad 2$ & 0.09 & 52 & & 0.590 & 0.599 \\
$\quad$ (b) Absolute no. of ants & & & & & \\
Host-plant flowering & 1 & 24.85 & 26 & 2.18 & 4.523 & 0.228 \\
Time (day of experiment) & 2 & 9.37 & 52 & 2.18 & 0.379 & 0.019 \\
Host-plant flowering $\times$ time & 2 & 0.83 & 52 & & 0.686 \\
\hline
\end{tabular}

as number of droplets excreted per treehopper in a standard period. To quantify the honeydew produced by an aggregation, a plastic sheet $(20 \times 20 \mathrm{~cm})$ was placed beneath the infested stem. The number of droplets flicked by the membracids (cf., Del-Claro \& Oliveira, 1996) onto the sheet within a 3-min period was counted and divided by the number of individuals in the aggregation (after $3 \mathrm{~min}$ the droplets tended to disappear due to evaporation; measurements taken between 0800 and $1100 \mathrm{~h}$ ). Each sheet with the honeydew droplets was then immediately stored in a portable freezer $\left(0^{\circ} \mathrm{C}\right)$ to minimise chemical decomposition. For the chemical analyses, the honeydew from other untended aggregations was also collected, giving a total of 10 honeydew samples from aggregations feeding on plants with flowers and 13 from plants without flowers (collections were made from a sheet under an infested stem, as described above). The chemical analysis of the honeydew gave an estimate of the total soluble sugar content per droplet of honeydew. Data were square-root transformed and $t$-tests were used to compare the flux of honeydew, as well as the concentration of sugar in the honeydew produced by the treehoppers on plants with and without flowers.

\section{RESULTS}

\section{Quality of phloem sap of plants with and without flowers}

The concentration of soluble sugar in the phloem sap differed significantly between plants with and without flowers $\left(t_{24}=2.882, P=0.008\right)$. The phloem sap of plants with flowers had $475.0( \pm 108.1 \mathrm{SE}) \mu \mathrm{g}$, and of plants without flowers $192.0( \pm 28.6 \mathrm{SE}) \mu \mathrm{g}$ of sugar/g of dry plant material.

No significant difference was detected in total nitrogen content of the phloem sap of plants with and without flowers $\left(t_{24}=-0.066, P=0.948\right)$. That of flowering plants had $9.32( \pm 1.0 \mathrm{SE}) \mathrm{mg}$, and that of plants without flowers $9.50( \pm 1.0 \mathrm{SE}) \mathrm{mg}$ of nitrogen/g of dry plant material.

\section{Honeydew quality and production}

No significant difference was detected in the concentration of soluble sugar in the honeydew produced by aggregations on plants with $(10.2 \pm 2.0 \mathrm{SE} \mu \mathrm{g}$ of sugar/drop of honeydew) versus plants without flowers $(7.4 \pm 1.5 \mu \mathrm{g})$ $\left(t_{21}=1.234, P=0.231\right)$. There was also no significant difference in the number of honeydew droplets produced by aggregations feeding on plants with or without flowers $\left(t_{13}=1.696, P=0.114\right)$. Over a 3 minute-period, aggrega- tions on plants with flowers produced $0.81( \pm 0.19 \mathrm{SE})$ droplets per individual, whereas those on plants without flowers produced 0.47 ( \pm 0.08 SE) droplets per individual.

\section{Ant tending and ant-derived benefits for treehoppers on plants with and without flowers}

Treehopper density on "Day 1" did not differ among the four treatments (Table 1; ANOVA, $F_{3,53}=0.19, P=$ 0.90). The species composition of the ant attendants at aggregations on plants with or without flowers was similar (Table 1). We found the same five ant species Camponotus abdominalis (Fabricius, 1804), C. crassus Mayr, 1862, C. aff. blandus (Fr. Smith, 1858), C. reng-
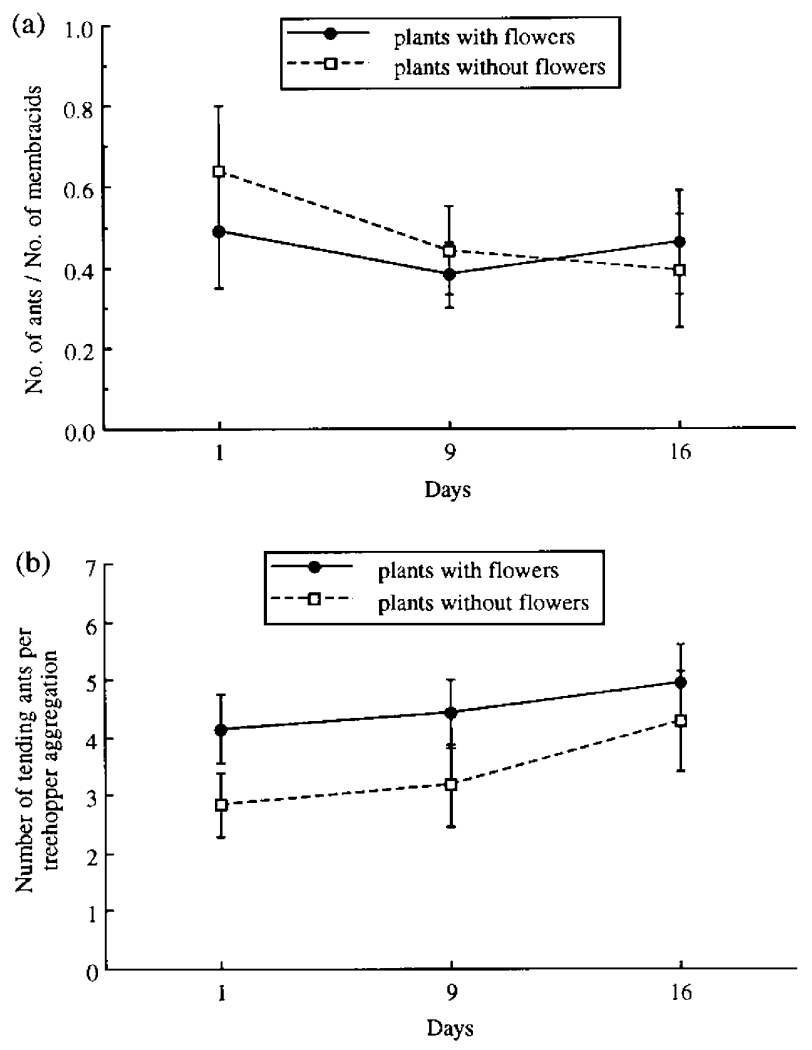

Fig. 2. Relative (a) and absolute (b) number of ants tending treehopper aggregations on plants with $(n=14)$ and without flowers $(n=15)$, on the $1^{\text {st }}, 9^{\text {th }}$ and $16^{\text {th }}$ day of the experiment. Values are means \pm SE. See also Table 2. 
TABLE 3. Two-way repeated-measures ANOVA on the effect of plant phenological status and ant attendance on (a) the number of treehoppers and (b) the natural enemies per plant through time. Plants with flowers: with ants $n=14$, without ants $n=13$. Plants without flowers: with ants $n=15$, without ants $n=14$. Calculations performed on square-root transformed data collected on the 1 st, 9th, and 16th day of the field experiment. See also Fig. 3.

\begin{tabular}{|c|c|c|c|c|c|c|}
\hline & df & Mean of square & df error & Mean of square error & $F$ & $P$ \\
\hline \multicolumn{7}{|l|}{ (a) Treehoppers } \\
\hline Host-plant flowering & 1 & 0.80 & 52 & 20.69 & 0.039 & 0.845 \\
\hline Ant treatment & 1 & 25.36 & 52 & 20.69 & 1.226 & 0.273 \\
\hline Time (day of experiment) & 2 & 1.34 & 104 & 3.54 & 0.378 & 0.686 \\
\hline Host-plant flowering $\times$ ant treatment & 1 & 3.61 & 52 & 20.69 & 0.174 & 0.678 \\
\hline Host-plant flowering $\times$ time & 2 & 3.28 & 104 & 3.54 & 0.925 & 0.399 \\
\hline Ant treatment $\times$ time & 2 & 14.05 & 104 & 3.54 & 3.967 & 0.022 \\
\hline $\begin{array}{l}\text { Host-plant flowering } \times \text { ant treatment } \times \text { time } \\
\text { (b) Natural enemies }\end{array}$ & 2 & 1.28 & 104 & 3.54 & 0.361 & 0.698 \\
\hline Host-plant flowering & 1 & 0.16 & 52 & 0.14 & 1.135 & 0.291 \\
\hline Ant treatment & 1 & 1.48 & 52 & 0.14 & 10.736 & 0.002 \\
\hline Time (day of experiment) & 2 & 0.38 & 104 & 0.09 & 3.827 & 0.025 \\
\hline Host-plant flowering $\times$ ant treatment & 1 & 0.33 & 52 & 0.14 & 2.397 & 0.128 \\
\hline Host-plant flowering $\times$ time & 2 & 0.53 & 104 & 0.09 & 5.289 & 0.006 \\
\hline Ant treatment $\times$ time & 2 & 0.13 & 104 & 0.09 & 1.279 & 0.282 \\
\hline Host-plant flowering $\times$ ant treatment $\times$ time & 2 & 0.13 & 104 & 0.09 & 1.352 & 0.263 \\
\hline
\end{tabular}

geri Emery, 1894 and C. rufipes (Fabricius, 1775) tending membracid aggregations on both these plant groups. Tending during the day was dominated by $C$. crassus and $C$. aff. blandus, while $C$. renggeri was the most dominant at night on all plants, irrespective of their flowering status (Table 1).

Neither the number of tending ants per membracid, nor the absolute number of ants, differed significantly between aggregations on plants with and without flowers (Table 2, Fig. 2a). However, the absolute number of ants visiting the aggregations increased significantly with time both on plants with and without flowers (Table 2, Fig. $2 b)$.

On both plant groups, the size of ant-tended aggregations increased while that of untended aggregations decreased significantly through time $(P=0.022$, see ant treatment $\times$ time interaction in Table 3a, Fig. 3a).

\section{Abundance of natural enemies}

The exclusion of ants resulted in a significant increase in the number of natural enemies both on plants with and without flowers (ant treatment effect in Table 3b). The overall number of natural enemies increased during the course of the experiment (time effect in Table 3b). However, plants with flowers accumulated more natural enemies through time compared to plants without flowers, irrespective of the ant treatment (host-plant flowering $\times$ time interaction in Table 3b, Fig. 3b). Post hoc comparisons (Newman-Keuls test) showed that natural enemies were indeed more abundant on day 16 on ant-excluded plants with flowers than on ant-excluded plants without flowers $(P=0.023)$, but did not differ significantly between ant-visited plants with flowers and ant-visited plants without flowers on that same day $(P=0.925$, see Fig. 3b). This latter result confirms the suppressing effect of tending ants on the number of natural enemies.
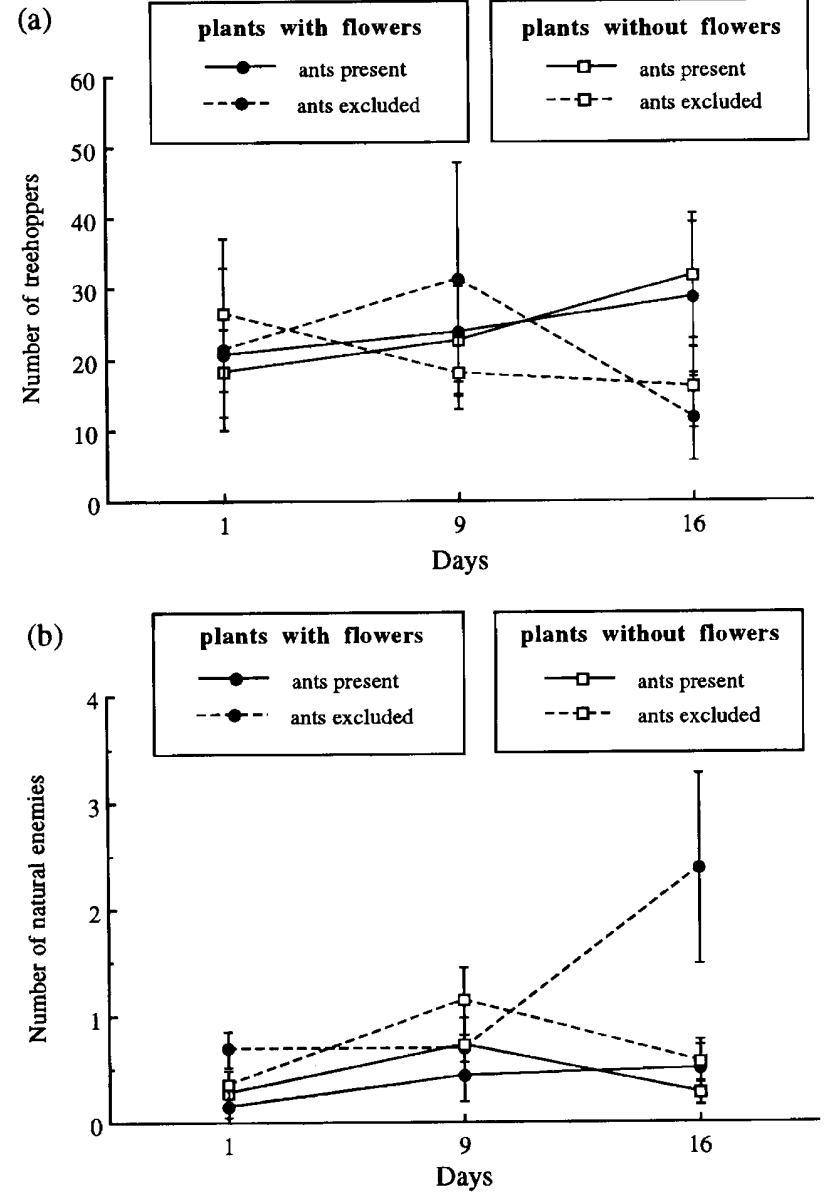

Fig. 3. Number of (a) treehoppers and (b) natural enemies per plant, on flowering and non-flowering plants of $D$. vinosum, on the $1^{\text {st }}, 9^{\text {th }}$ and $16^{\text {th }}$ day of the experiment. Plants with flowers: with ants $n=14$, without ants $n=13$. Plants without flowers: with ants $n=15$, without ants $n=14$. Values are means \pm SE. See also Table 3. 


\section{DISCUSSION}

This field experiment revealed that host-plant flowering status affected the quality of the food ingested by the membracid. Phloem sap from flowering plants was richer in sugars compared to that from plants without flowers. This difference, however, did not translate into a richer or more copious honeydew for tending ants on plants with flowers. Although the treehoppers survived better when tended by ants, host-plant flowering status had no effect on hemipteran attractiveness to ants, or on hemipteran survival.

By showing that amino acid concentration in aphid honeydew varied with season and leaf age, Douglas (1993) confirmed that host-plant characteristics could affect the nutrient concentration of hemipteran honeydew. Nitrogen is known to be an important limiting nutrient for herbivores (Mattson, 1980; Strong et al., 1984). However, in the current study total nitrogen concentration was the same for the phloem fluid of plants with or without flowers, and therefore we do not believe that honeydew from membracids feeding on plants with or without flowers would vary in nitrogen concentration. Although ants may assimilate amino acids from hemipteran honeydew (Woodring et al., 2004), sugar concentration and composition appear to be the most important factors mediating the interaction between ants and Hemiptera (Kiss, 1981).

Host-plant characteristics or species identity determine the sugar composition of hemipteran honeydew (Campbell, 1986; Hendrix et al., 1992; Fischer \& Shingleton, 2001) and this, in turn, can affect the level of ant tending (Völkl et al., 1999). Indeed, sugar concentration and composition appear to be the primary attractants for honeydew-gathering ants (Völkl et al., 1999; Fischer \& Shingleton, 2001) and recent studies indicate that the amino acids in the honeydew of several aphid species do not influence ant attendance (Woodring et al., 2004; but see Lanza, 1988; Bristow \& Yanity, 1999). Moreover, the main source of protein for many ants involved in these interactions, including Camponotus species, is live prey or dead animal matter (Buckley, 1987; Hölldobler \& Wilson, 1990; Davidson et al., 2003, and references therein).

Three factors may account for the higher accumulation of Guayaquila's natural enemies on plants with flowers compared to plants without flowers. First, the presence of flowers usually increases the complexity of plant architecture (i.e., more feeding sites, hiding places) and attracts a wider range of herbivore (prey) species than plants without flowers, which may result in an increased abundance of natural enemies on flowering plants (see Riechert, 1992; Cuautle \& Rico-Gray, 2003). Salticid spiders were observed preying on species other than Guayaquila on plants with flowers, so the wider range of prey species on plants with flowers may reduce the risk of predation for the treehoppers (cf., Krebs \& Davies, 1993). Second, spiders may feed on nectar (Jackson et al., 2001). Moreover, the adults of predatory syrphids and most parasitoid wasps feed on nectar and/or pollen (Jervis \& Kidd, 1996). Third, it is possible that Guayaquila mem- bracids feeding on flowering plants may be more nutritious (or palatable) for predators such as salticid spiders, which are commonly seen on the host-plant (15 species were recorded; see Del-Claro \& Oliveira, 2000). Indeed, Bristow (1991) showed that generalist predators prefer aphids (Aphis nerii) reared on floral tips of oleander (Nerium oleander) to those feeding on leaf tips. Finally, Hacker \& Bertness (1995) demonstrated that host-plant quality could have a cascading effect on the population dynamics of Uroleucon aphids by affecting the abundance of their predators, with better-quality tall plants attracting more predators than short plants of inferior quality.

A combination of the above mechanisms (alternate prey, increased abundance of nectar-feeding enemies and more nutritious prey) could potentially account for the accumulation of natural enemies on plants with flowers. By feeding on plants with flowers, Guayaquila membracids may also acquire more nutritional food for their own growth, in which case one would expect them to be bigger and/or develop faster (see Bristow, 1984). Although it needs to be confirmed, this scenario suggests a trade-off between feeding on a higher-quality phloem sap and living on a more dangerous plant individual. Because the protection afforded by ants is speciesspecific in the ant-Guayaquila system (Del-Claro \& Oliveira, 2000), some of the species of ants may not be effective protectors at certain plant locations (or at certain times) of increased abundance of natural enemies. The fact that ant tending levels and treehopper survival rates did not vary with plant flowering status suggests that the treehoppers are efficient at attracting ants (see Del-Claro \& Oliveira, 1996), and/or that a dilution of predation risk on plants with flowers in fact occurs. A possible metabolic constraint, however, has also to be considered (Douglas, 2003, see below).

This is the first field study to simultaneously test the three conditions associated with the hypothesis of hostplant mediation in ant-hemipteran mutualisms (Cushman, 1991; Cushman \& Addicott, 1991) and the first to determine the effect of plant flowering status (and quality phloem of sap) on ant protection of a honeydewproducing hemipteran. The results show that although ant attendance positively affects treehopper survival, hostplant phenological status has no effect on the level of ant tending, or on hemipteran survival. Thus host-plant mediation was not detected in this ant-hemipteran association using the parameters measured. The results suggest, however, that the way in which the host-plant might affect ant-Guayaquila interactions is likely to be complex and may involve indirect effects from other species (Bronstein \& Barbosa, 2002). Moreover, the physiological constraints inherent in sap feeding should also be taken into account in analyses of plant-hemipteran-ant interactions. For instance, recent evidence indicates that high sugar concentrations in phloem sap with pose considerable metabolic problems for aphids due to the hyperosmotic nature of this food (Douglas, 2003). Future studies on the Didymopanax-Guayaquila-ant system 
should determine the bottom-up effects of phloem sap quality on membracid growth and development, as well as the foraging behaviour of Guayaquila's natural enemies on host-plants at different stages of flowering. This study reveals that much work remains to be done on the trade-offs underlying ant-hemipteran associations.

ACKNOWLEDGMENTS. This study was supported by a fellowship from CAPES to T.Q., and research grants from FAPESP and CNPq to J.R.T and P.S.O. We thank N.E. Pierce, R.J. Marquis, K. Del-Claro, K.S. Brown, H.L. Vasconcelos, C.R. Fonseca, G. Ganade, R. Wirth, A.V. Freitas, H. Dutra, R. Cogni and L. Araripe for helpful comments on the manuscript. The final version was considerably improved by comments of five anonymous referees. A.X. Linhares and C.R. Fonseca provided statistical assistance, L. Deitz helped with membracid nomenclature and K. Del-Claro assisted with data on Didymopanax biology. We also thank the Instituto de Botânica de São Paulo for permission to work in the cerrado reserve and several colleagues for help in the field.

\section{REFERENCES}

Auclair J.L. 1963: Aphid feeding and nutrition. Annu. Rev. Entomol. 8: 439-490.

BRISTOw C.M. 1984: Differential benefits from ant attendance to two species of Homoptera on New York ironweed. J. Anim. Ecol. 53: 715-726.

BRISTOw C.M. 1991: Are ant-aphid association a tritrophic interaction? Oleander aphids and Argentine ants. Oecologia 87: 514-521.

BRistow C.M. \& YANity E. 1999: Seasonal response of workers of the Allegheny mound ant, Formica exsectoides (Hymenoptera: Formicidae) to artificial honeydews of varying nutritional content. Great Lakes Entomol. 32: 15-27.

Bronstein J.L. \& BARBosa P. 2002: Multitrophic/multispecies mutualistic interactions: The role of non-mutualists in shaping and mediating mutualisms. In Tscharntke T. \& Hawkins B.A. (eds): Multitrophic Level Interactions. Cambridge University Press, Cambridge, pp. 44-66.

BUCKLEY R.C. 1987: Interactions involving plants, Homoptera, and ants. Annu. Rev. Entomol. 18: 111-138.

CampBell B.C. 1986: Host-plant oligosaccharins in the honeydew of Schizaphis graminum (Rondani) (Insecta, Aphididae). Experientia 42: 451-452.

Cuautle M. \& Rico-Gray V. 2003: The effect of wasps and ants on the reproductive success of the extrafloral nectaried plant Turnera ulmifolia (Turneraceae). Funct. Ecol. 17: $417-423$.

CuSHMAN J.H. 1991: Host-plant mediation of insect mutualisms: variable outcomes in herbivore-ant interactions. Oikos 61: $138-144$.

Cushman J.H. \& Addicott J.F. 1989: Intra- and interspecific competition for mutualists: ants as a limited and limiting resource for aphids. Oecologia 79: 315-321.

Cushman J.H. \& Addicott J.F. 1991: Conditional interactions in ant-plant-herbivore mutualisms. In Huxley C.R. \& Cutler D.F. (eds): Ant-Plant Interactions. Oxford University Press, Oxford, pp. 92-103.

Cushman J.H. \& Whitham T.G. 1989: Conditional mutualism in a membracid-ant association: temporal, age-specific, and density-dependent effects. Ecology 70: 1040-1047.

Davidson D.W., Cook S.C., Snelling R.R. \& Chua T.H. 2003: Explaining the abundance of ants in lowland tropical rainforest canopies. Science 300: 969-972.
Del-Claro K. \& Oliveira P.S. 1993: Ant-homoptera interaction: do alternative sugar sources distract tending ants? Oikos 68: 202-206.

Del-Claro K. \& Oliveira P.S. 1996: Honeydew flicking by treehoppers provides cues to potential tending ants. Anim. Behav. 51: 1071-1075.

Del-Claro K. \& Oliveira P.S. 1999: Ant-Homoptera interactions in a neotropical savanna: The honeydew-producing treehopper Guayaquila xiphias (Membracidae) and its associated ant fauna on Didymopanax vinosum (Araliaceae). Biotropica 31: $135-144$.

Del-Claro K. \& Oliveira P.S. 2000: Conditional outcomes in a neotropical treehopper-ant association: temporal and speciesspecific effects. Oecologia 124: 156-165.

Dixon A.F.G. 1985: Aphid Ecology. Blackie, London, 136 pp.

Douglas A.E. 1993: The nutritional quality of phloem sap utilized by natural aphid populations. Ecol. Entomol. 18: 31-38.

Douglas A.E. 2003: The nutritional physiology of aphids. $A d v$. Insect Physiol. 31: 73-140.

FisCher M.K. \& SHingleton A.W. 2001: Host plant and ants influence the honeydew sugar composition of aphids. Funct. Ecol. 15: 544-550.

HACKER S.D. \& BERTNESS M.D. 1995: A herbivore paradox: why salt marsh aphids live on poor-quality plants. Am. Nat. 145: 192-210.

Hendrix D.L., Wei Y. \& LegGerr J.E. 1992: Homopteran honeydew sugar composition is determined by both the insect and plant species. Comp. Biochem. Physiol. (B) 101: 23-27.

Hölldobler B. \& Wilson E.O. 1990: The Ants. Harvard University Press, Cambridge, MA, 732 pp.

Jackson R.R., Pollard S.D., Nelson X.J., Edwards G.B. \& BARRION A.T. 2001: Jumping spiders (Araneae: Salticidae) that feed on nectar. J. Zool. 255: 25-29.

JeRvis M.A. \& KIDD N.A.C. 1996: Phytophagy. In M.A. Jervis \& Kidd N.A.C. (eds): Insect Natural Enemies: Practical Approaches to Their Study and Evaluation. Chapman and Hall, London, pp. 375-394.

Kearns C.A. \& Inouye D.W. 1993: Techniques for Pollination Biologists. University Press of Colorado, Niwot, 583 pp..

King R.W. \& ZeEvaArt J.A. 1974: Enhancement of phloem exudation from cut petioles by chelating-agents. Plant Physiol. 53: $96-103$.

KISs A. 1981: Melezitose, aphids and ants. Oikos 37: 382.

Krebs J.R. \& Davies N.B. 1993: An Introduction to Behavioural Ecology. Blackwell Science, Oxford, 464 pp.

LANZA J. 1988: Ant preferences for Passiflora nectar mimics that contain amino acids. Biotropica 20: 341-344.

MatTSON W.J. 1980: Herbivory in relation to plant nitrogen content. Annu. Rev. Ecol. Syst. 11: 119-161.

McEvoy P.B. 1979: Advantages and disadvantages to group living in treehoppers (Homoptera: Membracidae). Misc. Pub. Entomol. Soc. Am. 11: 1-13.

Oliveira P.S. \& Del-Claro K. 2005: Multitrophic interactions in a neotropical savanna: ant-hemipteran systems, associated insect herbivores, and a host plant. In Burslem D.F.R.P., Pinard M.A. \& Hartley S.E. (eds): Biotic Interactions in the Tropics. Cambridge University Press, Cambridge (in press).

Oliveira P.S. \& Freitas A.V.L. 2004: Ant-plant-herbivore interactions in the neotropical cerrado savanna. Naturwissenschaften 91: 557-570.

Oliveira P.S., Freitas A.V.L. \& Del-Claro K. 2002: Ant foraging on plant foliage: contrasting effects on the behavioral ecology of insect herbivores. In Oliveira P.S. \& Marquis R.J. (eds): The Cerrados of Brazil: Ecology and Natural History of a Neotropical Savanna. Columbia University Press, New York, pp. 287-305. 
Oliveira-Filho A.T. \& Ratter J.A. 2002: Vegetation physiognomies and woody flora of the cerrado biome. In Oliveira P.S. \& Marquis R.J. (eds): The Cerrados of Brazil: Ecology and Natural History of a Neotropical Savanna. Columbia University Press, New York, pp. 91-120.

PIERCE N.E. 1985: Lycaenid butterflies and ants: selection for nitrogen fixing and other protein rich food plants. Am. Nat. 125: 888-895.

Pierce N.E., Kitching R.L., Buckley R.C., Taylor M.F.J. \& BenBow K.R. 1987: The costs and benefits of cooperation between the Australian lycaenid butterfly, Jalmenus evagoras, and its attendant ants. Behav. Ecol. Sociobiol. 21: 237-248.

Price P.W., Bouton C.E., Gross P., McPheron B.A., Thompson J.N. \& WeIS A.E. 1980: Interactions among three trophic levels: influence of plant on interactions between insect herbivores and natural enemies. Annu. Rev. Ecol. Syst. 11: 41-65.

Price P.W. \& CARR T.G. 2000: Comparative ecology of membracids and tenthredinids in a macroevolutionary context. Evol. Ecol. Res. 2: 645-665.

QueIroz J.M. \& Oliveira P.S. 2001: Tending-ants protect honeydew-producing whiteflies (Homoptera: Aleyrodidae). Environ. Entomol. 30: 295-297.

Rico-Gray V. 1993. Use of plant-derived food resources by ants in the dry tropical lowlands of coastal Veracruz, Mexico. Biotropica 25: 301-315.

RIECHERT S.E. 1992: Spiders as representative "sit-and-wait" predators. In Crawley M.J. (eds): Natural Enemies: The population Biology of Predators, Parasites, and Diseases. Blackwell, Oxford, pp. 313-328.
Salisbury F.B. \& Ross C.W. 1992: Plant Physiology. Wadsworth Publishing Company, Belmont, 682 pp.

Stadler B. \& Dixon A.F.G. 1998: Costs of ant attendance for aphids. J. Anim. Ecol. 67: 454-459.

Strong, D.R., Lawton J.H. \& Southwood T.R.E. 1984: Insects on Plants: Community Patterns and Mechanisms. Harvard University Press, Cambridge, MA, 313 pp.

Vogel A.I. 1989: Textbook of Quantitative Chemical Analysis. Longman, London, $372 \mathrm{pp}$.

VÖlKL W., Woodring J., Fischer M., Lorenz M.W. \& HoffMANN K.H. 1999: Ant-aphid mutualisms: the impact of the honeydew production and honeydew sugar composition on ant preferences. Oecologia 118: 483-491.

WAY M.J. 1963: Mutualism between ants and honeydewproducing Homoptera. Annu. Rev. Entomol. 8: 307-344.

WHITE T.C.R. 1984: The abundance of invertebrate herbivores in relation to the availability of nitrogen in stressed food plants. Oecologia 63: 90-105.

Wood T.K. 1980: Divergence in the Enchenopa binotata Say complex (Homoptera: Membracidae) effected by host plant adaptation. Evolution 34: 147-160.

Woodring J., Wiedemann R., Fischer M.K., Hoffmann K.H. \& VÖLKL W. 2004: Honeydew amino acids in relation to sugars and their role in the establishment of ant-attendance hierarchy in eight species of aphids feeding on tansy (Tanacetum vulgare). Physiol. Entomol. 29: 311-319.

ZAR J.H. 1999: Biostatistical Analysis. 4th ed. Prentice Hall, New Jersey, 663 pp.

Received September 1, 2004; revised December 17, 2004; accepted March 7, 2005 